\title{
The role of the State and the quality of the public sector
}

\section{Vito Tanzi}

Director,

Fiscal Affairs Department, International Monetary Fund vtanzi@imf.org
The author of this article concludes that the quality of the public sector can be assessed only against the role of the State. In general, an efficient public sector should be able to achieve the State's objectives with the minimum degree of distortion of the market, with the lowest burden of taxation on taxpayers, with the smallest number of public employees, and with the lowest absorption of economic resources by the public sector. The public sector must be transparent in its processes and in its outcome. Corruption should have no part in the decisions made by bureaucrats and political leaders, and the resources in the hands of the public sector should be put to a use that maximizes their social rate of return. The quality of the public sector is also important for pursuing the objective of equity, which is now seen as one of the fundamental goals of the State. A high-quality public sector should make possible the pursuit of equity with the lowest costs in terms of efficiency. Finally, the so-called "first generation reforms" do not necessarily improve the quality of the public sector even though they may improve the quality of public policy. The pursuit of "first generation reforms" has, in fact, highlighted the need to improve the quality of the public sector, and for this to occur, "second generation reforms" are necessary. 


\section{I}

\section{The role of the State}

"What is the best government? That which teaches us to govern ourselves"

Johann Wolfgang von Goethe
Human beings are social animals, and as a consequence they tend to aggregate in groups. Aggregation generates markets and the need for social institutions. Markets and economic activities are characterized by specialization on the part of the participants. Specialization leads to exchanges, and exchanges involve contracts, which may be implicit or explicit. Implicit contracts prevail in primitive societies and are often enforced by existing moral and social codes. As societies develop, they require more explicit or formal contracts. These, in turn, require institutions to register them, when registration is required, and to enforce them. In market economies individuals also accumulate assets and this accumulation leads to the need for property protection. Furthermore, they need personal protection against criminal elements within their groups or against outsiders. Thus, any aggregation of individuals requires the existence of at least rudimentary institutions that perform these functions and that can be considered as a minimal form of State. This is the essential role of the State in a primitive society or its minimal role in any society. ${ }^{1}$

$\square$ This article aims to make a contribution to the literature on second generation reforms. A previous version was presented at the conference on second generation reforms organized by the International Monetary Fund in Washington, D.C., on 8 and 9 November 1999 and another conference on the control of public activities organized by the Banco di Italia in Perugia on 2 and 3 December 1999. The author wishes to express his gratitude for the valuable comments made on a preliminary version of this study by Era Dable-Norris, Barry Potter and Howell Zee as well as the views expressed by Patricio Castro, Jerome Fournel, Eduardo Ley, Istvan Székely and other participants in an internal seminar of the Fiscal Affairs Department of the IMF. The views expressed in this article are of course purely those of the author and should not be interpreted as representing the official position of the International Monetary Fund.

${ }^{1}$ There is now an extensive literature that argues that even gangs or criminal associations of individuals require within themselves some organization that is a rudimentary form of government. See Skaperdas and Syropoulos (1995), Charap and Harm (forthcoming), and various papers in Fiorentini and Zamagni (eds.) (1999). For the concept of a minimal, or even of an ultraminimal, State see Nozick (1974).
As societies become more complex and as the groups that constitute them become larger and less homogeneous, the State must assume additional responsibilities if it wishes to promote to the full the welfare of the individuals that comprise it. For example, markets are not efficient when they are distorted by monopolies or when essential information is not available to the participants, or is too costly for them to obtain. This leads to the need for the State to regulate markets and to provide at least some essential information to the population. Thus, institutions must be created to satisfy these needs (World Bank, 1997).

There are some goods (defence, city streets, etc.) that only the State can provide because private individuals would not find it in their interest to provide them. One important reason for this is that once these goods are provided, the provider will not be able to exclude from their use individuals who do not wish to contribute to the cost of providing them. Another reason is that once they are produced, they can be consumed jointly by everyone, so that it would be inefficient for society as a whole to exclude some individuals from their use. Consequently, if these goods are essential, they must be provided (though not necessarily produced) by the State. These are the "public goods" of economics literature. Furthermore, the production or consumption of some goods or activities generates positive or negative externalities which are not captured by those who consume or produce them. If the State does not intervene, the market is likely to under-produce or over-produce these goods or activities. Once again, there may be a need for the public sector to intervene. ${ }^{2}$

All the above are examples of a general role of the State which, in public economics literature, goes under the name of resource allocation (see Musgrave, 1959).

\footnotetext{
${ }^{2}$ The traditional form of State intervention is to tax those who generate negative externalities and to subsidize those who generate positive externalities.
} 
Although some problems of allocation can be dealt with by the use of regulations, often, if the State must perform this role, it will need resources. In principle, the State could directly appropriate these resources by forcing individuals to contribute their time or their wealth for the production of the required goods -as it does, for example, with compulsory military service or with some forms of expropriation. In medieval times roads were often built in this way. However, a more efficient alternative is to use resources raised through taxation. Thus, there is a need for a tax system and for institutions that collect taxes. And, of course, there is a need for institutions that spend the money and keep track of that spending. In all these activities, in a market economy the State is expected to minimize the cost that its activities impose on the market and on society at large. Thus, a public sector of high quality requires an efficient tax system and an expenditure system that minimizes inefficient and unproductive spending. It also requires a budget large enough to allow the State to perform its role in a satisfactory way (see Tanzi and Zee, 1997).

In addition to the essential or fundamental role of the State associated with the allocation of resources $-\mathrm{a}$ role that has been explicitly recognized and described by economists at least since Adam Smith's Wealth of Nations - two or even three additional economic roles have been assigned to the State in the present century. These are i) redistribution of income, ii) stabilization of economic activity, and iii) promotion of growth and employment. These latter tasks are less firmly based in economic theory than the allocation role, but they have been important in the practical implementation of policies in the second half of the twentieth century. ${ }^{3}$

Markets produce goods and services and provide incomes to those who participate in them. Depending on the initial situations of the individuals as regards ownership of real assets, of financial resources, and of human capital and talent in general, and also depending on their levels of effort, propensity to save, luck and risk taking, as well as on government policy, a given pattern of income (and wealth) distribution is determined. This distribution may or may not match the prevailing societal perception of the degree of inequality that is considered acceptable. Furthermore, because of physical or mental handicaps or other characteristics or situations, such as old age, unemployment, number of dependents in the family and so on, some individuals may not be able to

\footnotetext{
${ }^{3}$ These roles had not affected the behaviour of governments in market economies very much until the twentieth century.
}

generate an income sufficient to sustain themselves or their families. In these cases, in the twentieth century and in some countries, the State has been expected to provide them with transfers aimed at raising their consumption above a certain essential minimum level. ${ }^{4}$

The assignment of a redistributive role to the State has dramatically changed the character of its intervention in the economy because it has introduced into its actions purely political considerations or objectives. In fact, while the State's role in allocation may be defined (at least in principle) on the basis of technical and objective analysis, its proper redistributive role cannot be established objectively. For example, there is no objective way to determine the ideal Gini coefficient or the ideal ratio of the top quintile to the bottom quintile of the income distribution of a country. Thus, these decisions are unavoidably influenced by the biases of the individuals constituting the government in power.

Programmes aimed at redistributing income often require a lot of resources and the presence of institutions charged with their administration. For this reason, they tend to lead to large increases in public spending and in the level of taxation, as they have in the so-called "Welfare States". 5 At times, the redistribution objective has been pursued through progressive taxation, but more often than not it has required large bureaucracies and much public spending. In many countries a large proportion of the public employees are now engaged in the provision of public education and health services, and a large share of the total public spending of industrial countries goes for social programmes, including pensions. In some cases public employment has had the specific objective of redistributing income (see Alesina, Danninger and Rostagno, 1999).

Markets do not operate perfectly smoothly but are characterized by fluctuations that sometimes turn into recessions or even depressions that lead to growing unemployment and loss of output, and in the second part of the twentieth century they created another major justification for State intervention, namely, the maintenance of full or at least high employment and the stabilization of output. The promotion of this Keynesian objective is carried out by government officials and requires some corresponding institutions. These officials must have the

\footnotetext{
${ }^{4}$ In previous centuries religious groups played a similar role in helping the poorest.

5 The World Bank (1997) has argued that the process of taking over these new functions has distracted the State from its more fundamental role. Schansberg (1996) has argued that redistribution is often associated with poor policies that harm rather than help the poor.
} 
capacity to change tax revenue and/or public spending in order to influence aggregate demand in desirable directions, and they must have the information and the technical knowledge and wisdom to make the right decisions.

Finally, in recent decades governments have also promoted policies aimed at raising the rate of growth or at creating employment. Import substitution and industrial policies are examples of attempts that have been made to raise the growth rate. Manipulation of the work week and public investments in particular activities or regions are examples of attempts at raising employment. Whatever the wisdom of these policies, special institutions must be responsible for executing them.

We can summarize the role of the State in a market economy in the following way:

i) it must establish and enforce formal rules in the economy, including the enforcement of contracts and the protection of property rights, as well as rules governing the extraction and use of public revenue;

ii) it must provide a legal and regulatory framework that reduces transaction costs -that is to say, the cost of dealing with other individuals in economic matters-and promotes market efficiency (through strategic market intervention in cases of market failure or through the production of some essential information);

iii) it must provide public goods and deal with obvious cases of externalities which cannot be resolved by negotiations between the private parties involved;

iv) it must promote macroeconomic stabilization; and

v) it must promote a distribution of income that is consistent with the prevailing view of society.

In order to perform these functions, the State needs some rules and institutions.

The role of the State has changed over time and across countries (see Van Creveld, 1999), partly because of the influence of changing or different views about that role and the evolution of technologies which influence what the State should do. Therefore, the quality of the public sector should be assessed in the light of the objectives and priorities of the government at any given point in time. These objectives may vary depending on the current needs of a particular country, and at times they may even conflict with one another. The State plays its role through the set of rules, laws, and institutions that make up the public sector. The higher the quality of that sector, the easier it will be for the State to play its role.

The quality of the public sector is defined here as the characteristic that allows the State to pursue its objectives in the most efficient way. Although it is difficult to separate the two concepts, the quality of the public sector is not necessarily the same thing as the quality of economic policy. Thus, a distinction must be made between the quality of the public sector and the quality of the policies that a given government may be pursuing at a given moment. A high- quality public sector is simply the instrument that facilitates the formulation and implementation of government policies. A good public sector makes it easier for the government to pursue good policies, but even a high-quality public sector cannot guarantee consistently good economic policies, because it cannot prevent policymakers from occasionally pursuing poor policies. However, one would hesitate to call a public sector "high-quality" if poor policies were frequently pursued and one would expect to find a close relation between the quality of the public sector, as defined here, and the quality of economic policy. In other words, over time a high-quality public sector is likely to promote good policies and a low-quality public sector is likely to promote poor policies.

The definition of a high-quality public sector used in this paper differs from that of "good government" used by other writers. For example, La Porta, López-deSilanes, Shleifer and Vishny (1998) define good government as one that is "good for capitalist development". They do not distinguish between the quality of the public sector and the quality of public policies, yet a poor public sector will, of course, render the pursuit of good policies more difficult because it will not provide the government with the needed information and it will not guarantee that the policy decisions will not be distorted in the implementation stage (see, in this respect, Tanzi (forthcoming)). 


\section{II}

\section{The importance of rules}

In the previous section the broad categories of State intervention in the economy were described. Each of these categories requires specific programmes, and each programme requires a legal mandate. In democracies with market economies the mandate given to the State for intervention in the economy is often specified, first in the Constitution and then in numerous laws and regulations that give a specific content to the normally general principles enunciated by the Constitution. ${ }^{6}$ Thus, the Constitution and the laws and regulations establish the rules of the game that guide the actions of individuals and enterprises on the one hand and public institutions on the other. As North and Weingast (1994, p. 312) have pointed out, however, "[a] critical political factor is the degree to which the regime or sovereign is committed to or bound by these rules."7

\section{The role of constitutions}

The principles expressed in the constitution may be clear but are often not very specific. The constitution must be a living document that guides action, but it cannot address specific situations or anticipate activities or situations that did not exist when it was written. It has been reported that Napoleon rejected the draft of the constitution that the best legal minds of his time had prepared at his request because he felt that the document was too specific and thus potentially too restrictive and likely to become obsolete with the passing of time. He preferred a statement of general principles that could be interpreted with some flexibility over time. To a large extent the American constitution is a good example of such a statement. Only rarely has it required amendments, and the role of the Supreme Court in interpreting it has never been challenged.

Examples of constitutional principles that are not too clear abound. A well known example is Article 81 of the Italian Constitution, which seems to restrict deficit

\footnotetext{
${ }^{6}$ For a comprehensive treatment of the role of legal institutions see Davis and Trebilcock (1999).

${ }^{7}$ Under authoritarian governments or dictatorships the Constitution may play a marginal role. Stalin's Constitution for the Soviet Union was a very good one, but it did not prevent him from doing whatever he wanted. He was obviously not bound by constitutional limitations.
}

financing but, over the years, has been interpreted in ways that did not prevent the occurrence of large fiscal deficits (see Martino, 1989). Examples of excessively restrictive constitutional limits are also common. An important example of this is the 1988 Brazilian Constitution, which, in recent years, has prevented the national government from making important and badly needed reforms in fiscal federalism and in the pension system. Other examples are the Indian Constitution, which has prevented the introduction of a national sales tax, or the Pakistani Constitution, which has limited the scope of any sales tax imposed by the national government to goods only and has prevented the taxation of agricultural incomes (see also Dethier and Shapiro, 1998).

A problem with constitutions is that they tend to reflect the preoccupations and the political forces of the time when they are written. A good example of this characteristic is the Italian Constitution which came into force in 1948. Its first article sets the tone by stating that "Italy is a democratic republic founded on labour." It subsequently states, in Article 4, that all citizens have a right to work. In its third chapter (Title III), which specifically deals with "economic relations", it lists many rights of workers but only limitations on the property rights of individuals, specifying that the State: i) can put limits on the use of property; ii) can expropriate it for the national interest, and iii) can impose various limits on the use of property in order to "establish equitable social relations". An Italian author has contrasted this "Republic of the workers" with the old "Republic of the property owners" (see Rodotá, 1995, p. 352).

These limitations on property rights must be compared with Edmund Burke's opinion that "a law against property is a law against industry" or with Adam Smith's opinion that "[the] acquisition of valuable and extensive property ... necessarily requires the establishment of civil government. Where there is no property ... civil government is not so necessary". 8 If the proper economic role of the State in a market economy requires the protection of the property rights of individuals, as much recent literature has argued, ${ }^{9}$ the Italian Constitution -at least in

\footnotetext{
${ }^{8}$ Both cited in Landes, 1999, on pages 32 and 33 respectively. ${ }^{9}$ See, for example, Landes (1999), North and Thomas (1973), North and Weingast (1994),and Davis and Trebilcock (1999).
} 
its formal declarations- seems reluctant to assign that role to the State. It should therefore not come as a surprise that economic policies and institutions in Italy have developed in line with the Italian Constitution and have, at times, allowed policies (rent controls, expropriation of land with very low compensation, etc.) that are not consistent with the principle of protection of property. This may also explain why Italy has one of the lowest scores, in terms of "economic liberty", among the countries assessed by the experts of the Economic Freedom Network.

In conclusion, the role that constitutions play in determining the quality of the public sector in democratic market economies cannot be exaggerated. ${ }^{10}$ It is the Constitution that encourages or allows certain actions on the part of the governing body and the citizens. Thus, at least in principle, the laws and the regulations that govern a country must be consistent with the constitutional principles as interpreted by the Supreme Court or by an equivalent body. In recent years, there has been a trend in many countries to try to modernize their Constitutions. However, the results have not always been very satisfactory, and at times the revised constitutions have been poorly drafted, complex and confusing.

Some economists, including James Buchanan and Francesco Forte, have argued that the economic or fiscal role of the constitution should be one of establishing limits on governmental action, as is done for example in the Swiss Constitution. According to these authors, the constitution should stress what the State cannot do rather than what it should do (see Forte (ed.), 1998). These authors tend to favour limitations on tax rates, on levels of public spending, or on fiscal deficits, the objective obviously being to provide the greatest scope for the working of the market. The Maastricht Stability and Growth Pact might be seen as an example of such a limit in a constitution.

In some circumstances -and again Brazil comes to mind- a change in the constitution to remove obstacles to desirable and important reforms may be a necessary condition for raising the quality of the public sector and of public policy.

\footnotetext{
10 This of course assumes that the rule of law is well established in the country, so that the constitution is taken seriously. It also assumes that effective Supreme Courts exist. In Italy, the "constitutional court" started operating ten years after the approval of the Constitution (see Rodotá, 1995, p. 353).
}

\section{Laws}

While the constitution sets, or at least should set, the general principles that guide a country's policies, the latter are permitted and directed by specific laws. It could be argued in general terms that the quality of the public sector is enhanced when the laws are relatively few, are clearly written (and thus not subject to conflicting interpretations), are comprehensive, and do not conflict with each other. Difficulties have arisen when there are too many laws, they are not clear, and they do not cover all relevant areas of economic activities, or provide conflicting signals.

It has been reported that while some European countries have only a few thousand active laws, others have tens of thousands (see Ferro, Lo Faso and Salvemini, 1999). In such circumstances it may be difficult to find one's way in this legal jungle. The legal system may reflect a problem conceptually similar to that associated with the Y2K difficulty. It occurs because every time a new law is enacted, all the existing laws should be scrutinized and, if necessary, revised to make sure that all the elements in them are consistent with the new law. This, of course, does not happen. When the existing laws are very numerous, and especially when they are not clear, it is almost impossible to ascertain this. Thus, at some point elements imbedded in laws which were enacted in the past but are still on the books may be seen to conflict with the new laws. When this happens, the directives to citizens, as well as to the institutions charged with implementing the programmes contemplated by the laws, become confused. This problem could be termed one of legal inconsistency. It often characterizes the relations between national and subnational levels of government, or between, say, pension and health programmes on one hand and annual budget laws on the other. ${ }^{11}$ Zoning laws and laws dealing with the environment have also suffered from this problem. At times, one law and a given institution authorize a certain land use but another law and another institution prohibit this. These conflicts may lead to costly mistakes and to uncertainty about property rights, and could negatively affect market decisions.

Thus, to repeat, the quality of the public sector is enhanced when the laws are written clearly and cover all the necessary areas, when they do not lead either the public or public officials to make conflicting interpreta-

\footnotetext{
${ }^{11}$ For example, the budget law may assign a given budgetary allocation for the health sector but the laws that determine the performance of the health sector may call for a higher level of spending. See Reviglio (1999) for a specific example from Italy.
} 
tions, when their number is as small as feasible, and when they do not conflict with each other. Over the years there have been attempts on the part of some countries (France, Italy, New Zealand, Russia) either to codify the existing laws or to simplify them. However, as these actions would give benefits only over the long run, they do not get much political support and the attempts are often abandoned before they produce the necessary results. ${ }^{12}$

\section{Regulations}

Laws are often accompanied by specific regulations. ${ }^{13}$ These can be classified in three groups: economic regulations, safety regulations, and information regulations. Regulations explain procedures or elaborate on the content of the laws or simply impose rules on individuals and enterprises. In some cases the laws are so complex that they require a very large body of regulations. For example, the regulations covering the U.S. Internal Revenue Code are reported to cover 18,000 pages, while the Internal Revenue Code itself is some 2,300 pages long. Regulations issued by an executive authority or by a regulatory agency can themselves be very complex, may not be easily accessible by the public, and may overlap with other regulations. In some countries they may not even be published. ${ }^{14}$ Yet, as a recent OECD report states: "Regulation is perhaps the most pervasive form of State intervention in economic activity" (OECD, 1999, p. 179).

Because many forms of regulations do not require budgetary appropriations or formal approval by the legislature, they tend to be less scrutinized. Thus, there is often an oversupply of regulations and their interpretation is all too often left to the bureaucrats who administer them. Therefore, the possibility of confusion or even abuse is very high. Regulations have been identified by the literature on this subject as one of the major causes of corruption, because the bureaucrats in charge may abuse them for their personal gain (see Tanzi, 1998b). They have also been shown to impose very large welfare costs on the economy. ${ }^{15}$

\footnotetext{
${ }^{12}$ See, for example, Guy (1996), Braibant (1996), Mattarella (1994), Smith and Richardson (1999) and Tan and Tower (1992).

${ }^{13}$ Regulations may be legislated and thus be laws themselves, or they may simply be issued by public agencies.

${ }^{14}$ In a country in which I worked many years ago tax incentives regulations were not publicly available in any form. Thus, the bureaucrats making the decisions had all the knowledge and their decisions could not be challenged by the taxpayers. These cases of asymmetric information between the State and citizens are not uncommon. ${ }^{15}$ See United States Congress, Senate Committee on the Budget (1984); Dixit (1996); Laffont and Tirole (1993); FIEL (1988); OECD (1999), and Jacobs (1999).
}

Because of the dynamic character of economies, and because of fast technological change, it is common to find countries with too many anachronistic, useless or even damaging regulations and too few necessary regulations relating to new economic activities. ${ }^{16}$ This is an area where excess and scarcity often coexist. Many countries are now struggling to create needed regulations for the financial and banking sectors, for the use of the information superhighway (Internet), for genetic research, for the use of some drugs, and for several other important new areas.

To sum up, a high-quality public sector must have enough clear rules to guide economic (and other) activities, but not rules that are so numerous or so vague as to give excessive power to bureaucrats or to create uncertainty among those who make economic decisions. In general, the rules should specify what is not allowed rather than authorize what is allowed. Discretion by bureaucrats should whenever possible be kept to a minimum. It has been reported that there are countries where some routine activities such as a request for a tax incentive or an application to open a small enterprise may need 30 or 40 authorizations signed by public employees in as many agencies or offices (see, inter alia, De Soto, 1987). This cannot be consistent with a high-quality public sector or with an efficient market.

An important step would be to make a periodic inventory (say, every ten years) of all the existing regulations, so that a "regulatory budget" could be established and could be pruned of redundant and anachronistic regulations while complementing it with new required ones and clarifying the confusing ones. Such an attempt has been made, with mixed results, by a few countries including Hungary and Argentina. Such a process, while costly, would raise the overall quality of the public sector. Another useful step would be the creation of a onestop, or "single window" centre where individuals can obtain all the permits and authorizations they need for their activities. Such centres have been created in a few places and are reported to have led to the elimination of many existing regulations and a reduction in corruption. ${ }^{17}$

\footnotetext{
${ }^{16}$ A couple of years ago, it was reported in the American press that in California, bread had to be sold only in pieces of an exact, well specified weight. This regulation, which was still on the books, had been introduced at the beginning of the century when most buyers did not have scales, so that they could be easily cheated by unscrupulous bakers. In Italy and Germany discounts on sales by shops must be approved by the municipality and must be limited in time.

${ }^{17}$ Centres of this type now exist in Bologna (Italy) and in Salvador de Bahía (Brazil). In Bologna an attempt is being made to allow access to this one-stop centre through the Internet.
} 
In addition to the formal constitutional rules and the rules specified in the laws and regulations, the quality of the public sector may be affected by informal norms or arrangements that influence the economic behaviour of individuals and the behaviour of the public sector. Such norms i) influence the choice of presidents, ministers, and other high-level officials; ii) set the pattern of appointments in the civil service, and iii) influence con- tacts between the State and the private sector. ${ }^{18}$ These informal norms may be based on religious, social or political considerations. Since they are of an informal nature and are based on cultural characteristics, they are difficult to change. Even so, the application of armslength relationships and the rule of law in all aspects of public sector behaviour should be a goal in the search for a higher-quality public sector (see Tanzi, 1995).

\section{III}

\section{Political and procedural rules}

The constitution, the laws and the regulations establish the broad legal powers of the public sector; or, to put it differently, they set the rules of the game that should determine the behaviour of the public sector and the regulation of the market. The importance of these rules cannot be overestimated. Several authors, including Buchanan, Alesina, von Hagen, Poterba, Tabellini and Persson, have argued that political arrangements such as fiscal federalism and fiscal decentralization, proportional or non-proportional representation in parliaments, the frequency of elections, the choice of presidential versus non-presidential types of governments, the role of the ministry of finance as a super-ministry, the rules that apply to the budgetary process (for example, whether it starts with a macroeconomic constraint which reflects a collective view on priorities or whether it allows pressures for spending to be determined through the political influence of each minister), whether parliament can modify the content of budgetary proposals or must vote on the whole budget, whether the central bank is independent, and so on have a significant impact on fiscal and macroeconomic outcomes. ${ }^{19}$ These situations have been modelled using strong assumptions and sophisticated game theories and have subsequently been sub-

\footnotetext{
${ }^{18}$ In some countries high public positions are almost inherited. Some jobs in particular institutions are passed from one member of a family to another. In others, party affiliation facilitates access to government jobs and a change in government creates a large number of vacancies because many jobs are considered as political appointments.

${ }^{19}$ Ricardo Haussmann has argued in support of a politically independent Fiscal Council that would restrict annual public debt accumulation to agreed levels. The analogy with the idea of an independent central bank is obvious. Others have argued in favour of a fiscal policy that to some extent is insulated from political pressures (see, for example, Blinder (1997) and Kopits and Symansky (1998)).
}

jected to empirical testing (see, among others, Tabellini and Persson (forthcoming) and Poterba and von Hagen (eds.), 1999).

I will not review this literature, which is still evolving and which, at times, has come to conflicting conclusions. While recognizing its importance and its potential contribution to explaining economic policy, the focus in the present paper is on other aspects and, specifically, on the quality of the public institutions. Political and procedural rules are more likely to affect policies than the quality of the public sector or of public institutions. It is the institutions that confront the citizens and implement the policies. But, of course, by changing the incentives under which policy-makers and institutions operate, the political and procedural rules may affect the behaviour and thus the quality of the institutions, and vice versa. The rules are just a set of instructions. They are not yet the policies. Until the game is played, these rules remain just pieces of paper, and the game is played by the institutions charged with carrying out these instructions, ${ }^{20}$ which may or may not carry out the instructions in a faithful and efficient way. ${ }^{21}$ The public sector is composed of many institutions, some more important than the others. It is the performance and efficiency of these institutions which, to a large extent, determine the quality of the public sector.

\footnotetext{
${ }^{20}$ It can be argued that there are two sets of games taking place. The first is the one that sets the rules and the second is the one that implements them.

${ }^{21}$ In a recent paper I argued that public policy is often distorted by the existence of principal-agent problems (see Tanzi (forthcoming)).
} 


\section{IV}

\section{The quality of public institutions}

The quality of the public sector may be affected by the absence of some essential institutions or by the poor performance of the existing institutions. For example, in many countries there are no institutions responsible for enforcing competition, for forcing full disclosure on the part of financial institutions or for obliging enterprises whose shares are traded on the stock market to present proper accounts. As a consequence, the market may function less well because of cronyism and monopoly powers or because of lack of essential information. The performance of public institutions depends on many factors including i) tradition and reputation; ii) the resources they have available and the discretion over their use; iii) the clarity of their mandate; iv) their organization; v) the incentives they are given; vi) the quality of their leadership and staff, and vii) the freedom they have in terms of reorganization.

Let us take one of the most fundamental institutions as an example: namely, the tax administration. Its performance will depend in part on its tradition and reputation. A tax administration which has been efficient, honest, and proud of its work in the past is likely to continue to be so in the future unless it suffers truly fundamental shocks. By the same token, it is very difficult in the short run to change a corrupt and inefficient administration. ${ }^{22}$ Its performance will also depend on the resources that it has available for hiring capable employees and paying good salaries, investing in new computer technology, carrying out necessary audits and so on. The clarity of its mandate -for example, to enforce the tax laws fairly and objectively- is also important, while its day-to-day independence from political pressures is essential. When the mandate becomes unclear, either because the laws are not transparent or because the institution is subjected to political interference that forces it to accommodate to the special circumstances of some taxpayers, problems develop. This has been the case, for example, in some transition economies and some developing countries, ${ }^{23}$ where political interference has reduced the quality of the tax administration. The organization of the tax ad-

22 Occasionally countries have opted to close down unsatisfactory offices or departments and open new ones, thus starting again from scratch.

${ }^{23}$ See for example Tanzi, 1998a. ministration is also important, as is the set of incentives that it is given. If an institution is poorly organized, or if good or bad performances are equally rewarded, the contribution of that institution to the quality of the public sector will be low. ${ }^{24}$

Attempts are currently being made to strengthen the incentives for good tax administration by making such administrations politically independent, like the central banks, ${ }^{25}$ and by negotiating explicit contracts between the government and the tax administration that require quantitatively specified levels of performance. In Australia, for example, the government guarantees the tax administration a given level of resources over a threeyear-period, and in return the tax administration undertakes to deliver certain quantifiable results and outputs. ${ }^{26}$

This brings us to two other important and related aspects of public institutions, namely i) the synergy among public institutions, and ii) the enforcement mechanisms. These are treated here as two separate aspects, although to a large extent they are two faces of the same coin.

\section{Synergy}

Like different elements of an ecological system, public institutions work together and support one another, so that it may not be possible to have, say, a first-class tax administration in an environment where other institutions, such as the treasury or other important ministries, the judiciary, or even the post office do not function well. ${ }^{27}$ Often the same weaknesses affect different institutions, so that attempting to improve just one institution, when the others need equal attention, is not likely to generate the desired results in the long run. This has

\footnotetext{
${ }^{24}$ The rules on hiring, promotion, firing and other matters relating to public servants obviously also play an important role in determining the quality of the public sector.

${ }^{25}$ Thus, the tax administration is given greater discretion in the use of resources.

${ }^{26}$ The cost of collection may be of importance in this context. See, for example, Highfield (1999).

${ }^{27}$ For example, in countries where tax evaders are not punished by the courts, it will be more difficult for a tax administration to fight tax evasion. In countries where the mail does not operate well, it will be difficult for the tax administration to rely on it to contact taxpayers and vice versa.
} 
been the experience in transition economies where, for example, the establishment of a good treasury system has not improved the quality of public expenditure management much because the budgetary process has continued to generate budgets that are so unrealistic that no treasury could finance or manage them. In some of these cases the result has been the accumulation of arrears on the part of the government, matched by a similar accumulation of arrears by taxpayers (see Potter and Diamond, 1999).

Inter-institutional externalities (either positive or negative) are very important and must be recognized and dealt with in any attempt at improving the quality of the public sector, although unfortunately, as far as I know this aspect has not been addressed in the literature. For example, when the judiciary does not work well, many other institutions suffer. The same could be said of the educational system. A holistic approach that simultaneously addresses problems in different institutions is likely to be necessary. However, such an approach, which is inevitably difficult to follow, must be guided by a clear strategy and by the proper sequencing of the changes required and made. If this approach requires more time to implement than the political horizon of the government that introduces it, it is less likely that it will be fully implemented. This is the reason why the quality of the public sector changes only slowly over time.

\section{Enforcement mechanisms}

The quality of the public sector will depend to a considerable extent on the existence of controls and enforcement mechanisms. Some of these mechanisms must operate within the institutions themselves. For example, efficient internal auditors' offices can improve the functioning of the institutions and provide some guarantees that the latter will not stray away from their basic mandate. But these mechanisms may not be sufficient. In other cases the enforcement mechanisms must cut across institutions, as occurs when top-level audit institutions specializing in controls and enforcement have responsibility for controlling spending and revenue collection. These institutions often draw their mandate from the constitution itself and act as independent bodies.

Examples of such top-level audit institutions are the General Accounting Office (GAO) in the United States, the Cour des Comptes in France, the Corte dei Conti in Italy, the Comptroller-General's Office in many Latin American countries, and so on. Historically, these audit institutions have focused too much on whether the institutions have complied with the letter of the law rather than its spirit. Thus, in many cases they have paid less attention to the performance of the institutions in terms of outputs and outcomes than to the question of whether they have complied with legalistic requirements. This kind of auditing is of limited value, except, perhaps, for ensuring accountability, because it does not promote the quality of the public sector in its fundamental objective of serving the public. It does not guarantee that the public is getting value for the money spent by the public sector.

In recent years there has been a movement to focus on performance and output, rather than on formalities and on input. This movement tries to assess public spending in terms of its economy, efficiency and effectiveness. It requires quantitative indicators of public performance and of the cost of public sector activities. It has had its strongest expression in New Zealand and Australia, but it has also been spreading to other countries in modified forms. ${ }^{28}$ It has brought with it many changes in contractual arrangements and in the organization of public institutions. For example, in the countries that have adopted it, civil service jobs no longer carry lifetime tenure and many constraints on the actions of those who run departments have been removed. The government, as the principal, now makes contracts with a public agency on what the latter must deliver, and the head of that agency becomes personally responsible for the outcome. If the agreed goals are not met, the contracts of the heads of the agencies are not renewed or their salaries are reduced. Thus strong economic incentives are being linked to performance. The final impact of these changes in countries whose cultures are very different from those of Australia and New Zealand remains to be assessed. ${ }^{29}$ It would be hard to implement these changes, for example, in countries where it is difficult to fire workers, almost regardless of their performance. It is easy to see the conflict between this approach and the spirit of the Italian Constitution.

\footnotetext{
${ }^{28}$ While the Australian system initially focused on the outcomes of public spending, the New Zealand system has always concentrated on the measurable output. It should be clear that outputs and outcomes are not the same thing. Outcomes may be more difficult to measure and may be affected by public spending, but with long lags. For example, educational spending may be assessed in terms of students in school (an output) or in terms of growth in human capital (an outcome). Health spending may be assessed in terms of operations performed or in terms of impact on the length and the quality of life. Obviously, the goal of the government should be to influence outcomes, but these are more difficult to measure than outputs.

${ }^{29}$ For a skeptical assessment of these changes, see Schick (1998).
} 
This discussion of enforcement mechanisms and controls would not be complete without a reference to two fundamental points. ${ }^{30}$ The first is the weakness of the cash accounting approach, which has traditionally been used for the measurement of government operations, as a means of securing good efficiency controls. The second is the measurement of consumer reactions and preferences with respect to the services rendered by public agencies, which has only recently begun to be studied. Before addressing these two points, it is important to mention that any concept of the quality of government services must be related to the cost of those services and to the resources available for generating them. The greater the resources available, the better one should expect the public services to be. For a given level of available resources, however, the higher the efficiency of the public agency, the higher will be the quality of the services provided.

The first question, then, is how to measure the level of resources used. Traditionally, the fiscal accounts (and hence the budget) have relied on cash accounting or cash transactions. Thus, the cost of, say, agency $\mathrm{X}$ is measured by the cash transfer that agency $X$ receives from the budget. However, accounts based on cash transactions have many weaknesses which are now more fully recognized by accountants and economists. The need for accrual accounting is now well established, at least, in principle, although practical difficulties in its use are likely to delay for some time the transition from cash accounting. ${ }^{31}$ Accrual accounting measures much more accurately the true costs of public sector activities, and it would thus make possible audits that are more meaningful in comparing outcomes with true costs. For example, cash accounting ignores the opportunity cost of using public sector assets if this use does not result in cash transfers (see Tanzi and Prakash (forthcoming)). Thus, an activity that receives only small cash transfers but uses very valuable land or buildings is now assessed as having low costs, which is obviously wrong.

The second question relates to the role of citizens, as taxpayers and consumers of public services, in evaluating the latter. Most of the reforms to date - particularly those agency-based reforms that distinguish between principal (the government) and agent (the public agencies)- represent actual or implicit contracts between two

\footnotetext{
${ }^{30}$ I am grateful to Barry Potter for calling my attention to these two points.

${ }^{31}$ The Department of Statistics of the IMF is in the process of producing a new manual of government finance statistics based on accrual accounting.
}

producer interests. An example from the private sector might be a contract between a regulatory body for the private sector and the monopoly industry it regulates. The regulatory body is supposed to represent the consumer in some sense, but its direct role is basically to avoid excessive profits for the producer rather than to specifically protect consumer interests. What is missing in the administrative arrangements in Australia and New Zealand is the voice of the consumer. Unlike the private sector, where consumers can state their preferences directly (providing there is an adequate degree of competition within the market), this possibility does not exist in public services. Therefore, some reforms in the 1990s have been aimed at trying to find surrogate indicators of consumer preferences. At least three approaches are worth mentioning in this respect:

i) Some evaluation studies have canvassed the views of particular consumers, not in relation to an organized consumer survey, but as part of a wider exercise aimed at finding out, for example, parents' views on the education given to their children. Such exercises have tended to be partial and confined to individual sectors.

ii) Another approach has been based on formal consumer surveys that may cover a number of different services. The World Bank and individual countries or institutions have carried out some initiatives in this area. ${ }^{32}$ While this does represent an advance on the past, the limitations of this approach are also significant. First, it is essentially opinion-related rather than measuring some actions or providing specific responses by the consumer to quality concerns. Second, it is subject to the usual problem that a well-designed survey can produce more positive views than might really be justified of services provided by the public sector.

iii) These weaknesses in both evaluations and consumer survey-type approaches led the United Kingdom in the early 1990s to seek an alternative approach. From this emerged the "Citizens' Charter", which tries to involve the citizens in the setting of standards. This has been done in a number of ways. Citizens' representatives or other consumer interest groups are also involved in the setting of standards and performance contracts between the government and agencies, not just the ministry of finance. Moreover, having set standards, consumers are also given the right and means to complain, through the provision of telephone hot lines, etc. Consumer response is taken into account when assessing the

\footnotetext{
${ }^{32}$ For example, users of public hospitals have been asked to assess the quality of the services provided, or taxpayers have been asked their opinions on some aspects of tax administration.
} 
overall performance of an agency manager. The compulsory use of name badges for officials -so that consumers can identify them and send in responses that reward good service and punish bad attention- is a small but significant element. This is still another example of how incentives are slowly being introduced in the public sector. Furthermore, in certain cases consumers are entitled to some form of compensation, if the public service provider fails to meet the required standards. The simplest example is that season ticket holders on certain rail services are entitled to refunds if delays in the running of the trains exceed a certain limit.

None of these approaches is wholly satisfactory, but at all events the inclusion of consumers' views in setting standards and commenting upon their compliance or otherwise, and thus influencing the future allocation of public sector resources, is likely to become a major theme over the next few years. It is also likely that incentives and penalties will play an increasing role in promoting a higher quality public sector.

In addition to the internal controls and those performed by auditing institutions such as the GAO or the Cour des Comptes, there are some other institutions whose work and efficiency are an essential ingredient in the quality of the whole public sector. Among these the system of justice is of the greatest importance. The role of the justice system in all its manifestations in enforcing contracts, in protecting property rights, in ensuring the safety of individuals, in keeping corruption under control, and in improving the efficiency of other institutions is fundamental. Thus, it is no exaggeration to say that the quality of the public sector of a country and the functioning of its market depend significantly on the performance of its justice system. It is for this reason that the system of justice is receiving a lot of attention in many countries, including European countries such as France, Italy and Portugal and the majority of Latin American countries.
In many countries the system of justice has been in crisis in recent years. Individual and property rights are not protected, contracts are not enforced, processes take years or even decades to be concluded, and so on. In many cases individuals who break the law are not punished, are punished only lightly, or are not punished until much later, when the deterrent effect of the punishment is lost. In some countries, the slow-moving or even corrupt system of justice has provided an implicit incentive for tax evasion, corruption and other illegal activities, because those caught committing crimes can count on the inefficiency or corruptibility of the justice system in order to escape punishment. In some countries it takes ten years for the government to determine whether someone accused of tax evasion should really pay the taxes claimed or not. Furthermore, often the penalties imposed are insignificant. This is a good example of the crossinstitutional externalities mentioned earlier. The same may occur in the case of those who do not comply with the terms of contracts. For example, the proliferation of bad loans and of financial crises is in part a direct consequence of the excessively low and much-delayed penalties on those who do not comply with the terms of their contracts. ${ }^{33}$ In some countries apartments or houses are left empty, rather than being rented out, because of the difficulty that the owners would have in reclaiming them at the end of the contract. The failure of the justice system clearly encourages tenants to ignore the terms of their contracts, and imposes efficiency costs on society as a whole.

When justice is corrupt or inefficient, it also becomes unjust, because some people are more adroit at taking advantage of its weak points. Law-abiding citizens are the ones who end up paying a higher price, and economic activity suffers. Equal access to justice -and to justice that is administered in a timely fashion- must remain one of the fundamental goals of the State. It is also one of the main requirements for an efficient market. If this goal is not met the quality of the public sector will remain poor (see Guigou, 1999).

\footnotetext{
${ }^{33}$ In many countries bankruptcy has become almost a trivial matter, of little consequence. The establishment of suitable bankruptcy laws has therefore become an important issue in such cases.
} 
V

\section{Measuring the general quality of the public sector}

Although knowledgeable individuals may have an $a$ priori idea of the general quality of the public sector of a given country, it would be difficult or even impossible to make objective measurements of that quality. In principle, one could conduct surveys of perceptions of such quality, using the same techniques adopted, for example, in surveys of corruption. In order to obtain acceptable results, however, the informational requirements on the part of the respondents would be extremely high, so that the quality of the responses would tend to be low. It might be easier to evaluate the quality of each of the major institutions that make up the public sector and somehow weigh their importance for the general quality of the public sector. However, given the number of such institutions and the knowledge required to assess them, such an exercise would also be very costly and would not necessarily achieve the desired results. An alternative way would be to simply measure the economic and social performance of a country, focussing on the output or, better, on the outcome and attributing the results obtained to the quality of the public sector. However, this approach would also have its limitations.

In recent years some institutions and scholars have begun to focus on particular features that capture some significant aspects of the quality of public sectors. The IMF, for example, has been focussing on types of statistics that countries could produce and make available to the public. Some of these data relate to the public sector. The assumption would be that countries that are willing and able to generate good public sector data and make them available on a timely basis to the public have a higher quality public sector. ${ }^{34}$ The Fund has also started to assess the transparency of fiscal policy and fiscal institutions in the light of a set of general principles of fiscal transparency. The assumption is that lack of transparency is an indication of lower quality of the public sector and that this lack of transparency promotes inefficiency, poor policies, and various problems of governance. In time, transparency reports could be available for most countries. If they were comparable and com-

${ }^{34}$ The data themselves might tell more about the quality of public policy than the quality of the public sector. prehensive, these reports would serve as proxies for informal assessments of the quality of the public sector.

In recent years, a lot of attention has been paid to issues of governance and corruption in public institutions. These issues also bear on the quality of the public sector. It has been recognized that lack of transparency in the way institutions operate and lack of controls promote inefficiency and corruption. There is now a large literature on transparency and on corruption. Australia and New Zealand have once again led the way in promoting techniques aimed at increasing transparency. In the new "architecture" of the international financial system, it is recommended that countries should become more transparent in their policy-making. More transparency would probably mean less corruption and generally a higher-quality and better-performing public sector. However, much needs to be learned about these relationships. It must also be recognized that tests of transparency may be either superficial or deep. Superficial tests would not be very useful for understanding what is going on in a public sector, while deep tests might require a large amount of highly specialized and costly resources.

Corruption is certainly a sign of a low-quality public sector. Various groups have been preparing corruption indexes for a large number of countries (see Tanzi, 1998b). These indexes claim to measure "perceptions" of corruption. It is likely that to some extent, and assuming that the perceptions reflect reality, these indexes of corruption can also be taken as proxies for the quality of the public sector. However, caution is needed because, quite apart from the quality of the corruption indexes, a country could have a totally honest bureaucracy or political leadership but very inefficient policies and institutions. Although important, corruption is only one aspect of poor public sector quality.

Some authors, such as Rauch and Evans (forthcoming), have provided estimates of bureaucratic performance for many developing countries, thus providing measures of yet another variable that has a bearing on the quality of the public sector. Keefer and Knack (1997), for their part, after defining institutional quality as "objective evaluations ... of the institutions that protect property and contractual rights", attempt a measurement based 
on several indicators, but it is not clear to what extent these measure the quality of public sector institutions.

There are also other variables that may provide information on the quality of the public sector. Some relate to its efficiency, some to the policies followed. For example, the relationship between spending in a given category -say health and education- and the outcome of

\section{VI}

\section{Conclusions}

The quality of the public sector can only be assessed against the background of the role of the State. If the public sector allows the State to promote its goals in an efficient and successful way, it can be argued that the public sector is of high quality. However, the goals must be realistic because even a very efficient public sector will be unable to fulfill unrealistic goals. Thus, in general the quality of the public sector cannot be measured by the quality of the policy outcome, although the two are obviously closely linked, especially over the long run.

In general, an efficient public sector should be able to achieve the State's objectives with the minimum degree of distortion of the market, with the lowest burden of taxation on taxpayers, with the smallest number of public employees, and with the lowest absorption of economic resources by the public sector. The public sector must be transparent in its processes and in its outcome. Corruption should have no part in the decisions made by bureaucrats and political leaders, while the resources in the hands of the public sector should be used in a way that maximizes their social rate of return. Such a public sector would be clearly "market augmenting", to use a now fashionable expression, and it would pay particular attention to the protection of property rights and the enforcement of contracts. that spending -such as lives saved, successful operations, reduction in the incidence of certain diseases, educational achievements- would be an indication of efficiency (see Gupta, Honjo and Verhoeven, 1997). On the other hand, measurements of fiscal sustainability might be indications of poor policy rather than of poor quality of the public sector.
The quality of the public sector is also important in the pursuit of equity, which is now seen as one of the fundamental goals of the State. A public sector which facilitates the pursuit of equity in all its aspects must, ceteris paribus, be deemed of higher quality than one that does not do so. However, as argued earlier, it is difficult to determine the optimal role of the State in this area, and it is easy to see how some policies that redistribute income can have disincentive effects. These effects are more likely to arise when the public sector is of low quality and thus makes it easier for policies to be distorted during the implementation stage (see, for example, Alesina, Danninger and Rostagno, 1999, and Schansberg, 1996). A high quality public sector should make possible the pursuit of equity at the lowest cost in terms of efficiency. ${ }^{35}$

Finally, the discussion in this paper should have made it clear that the so-called "first generation reforms" which have been so popular in many countries in the 1980s and 1990s do not necessarily improve the quality of the public sector, even though they may improve the quality of public policy. The pursuit of "first generation reforms" has, in fact, highlighted the need to improve the quality of the public sector, and for this to occur, "second generation reforms" are necessary.

(Original: English)

\footnotetext{
${ }^{35}$ An important role in this area has been assigned to the State by Sen (1999), who identifies development with freedom and who assigns to the State the function of providing access to education and health for all. A high-quality public sector would facilitate the achievement of Sen's objective.
} 


\section{Bibliography}

Alesina, A., S. Danninger and M. Rostagno (1999): Redistribution Through Public Employment: The Case of Italy, IMF working paper, No. 177, Washington, D.C., International Monetary Fund (IMF), December.

Blinder, A. (1997): Is government too political?, Foreign Affairs, vol. 76, $\mathrm{N}^{\circ} 6$, New York, Council on Foreign Relations, Inc.

Braibant, G. (1996): Utilité et difficultés de la codification, Droits, $\mathrm{N}^{\circ} 24$, Paris, Presses Universitaires de France, December.

Charap, J. and C. Harm (forthcoming): Institutionalized corruption and the kleptocratic State, in C. Menard (ed.), Institutions, Contracts and Organizations: Perspectives from New Institutional Economics, Northampton, Massachusetts, Edward Elgar.

Davis, K. and M. J. Trebilcock (1999): What role do legal institutions play in development?, paper presented at the Conference on Second Generation Reforms, Washington, D.C., IMF, 8-9 November.

De Soto, H. (1989): The Other Path, New York, Harper and Row.

Dethier, J. J. and T. Shapiro (1998): Constitutional rights and the reform of social entitlements, in L. Bokros and J. J. Dethier (eds.), Public Finance Reform During the Transition: The Experience of Hungary, Washington, D.C., World Bank.

Dixit, A. K. (1996): The Making of Economic Policy, Cambridge, Massachusetts, MIT Press.

Ferro, P., S. Lo Faso and G. Salvemini (1999): L'azione della pubblica amministrazione per la competitività internazionale in presenza di vincoli di finanza pubblica, in M. Bordignon and D. Da Empoli (eds.), Concorrenza fiscale in un'economia internazionale integrata, Rome, Franco Angeli.

FIEL (Foundation for Latin American Economic Research) (1988): Los costos del Estado regulador, Buenos Aires.

Fiorentini, G. and S. Zamagni (eds.) (1999): The Economics of Corruption and Illegal Markets, Northampton, Massachusetts, Edward Elgar.

Forte, F. (ed.) (1998): Le regole della costituzione fiscale, Politeia, vol. 14, $\mathrm{N}^{\circ}$ 49, Milan, Politeia.

Guigou, E. (1999): Justice: Du Ministère des Affaires au Ministère du Droit, Le Monde, Paris, 1 September.

Gupta, S., K. Honjo and M. Verhoeven (1997): The Efficiency of Government Expenditure: Experiences in Africa, IMF working paper, $\mathrm{N}^{\circ} 153$, Washington, D.C., IMF.

Guy, S. (1996): Une utopie: la codification, Revue française de droit constitutionnel, $\mathrm{N}^{\circ}$ 26, Paris, Presses Universitaires de France.

Highfield, R. (1999): Tax administration: Understanding and using the cost of collection ratio, Washington, D.C., November, mimeo.

Jacobs, S. H. (1999): The second generation of regulatory reforms, paper presented at the Conference on Second Generation Reforms, Washington, D.C., IMF, 8-9 November.

Keefer, P. and S. Knack (1997): Why don't poor countries catch up? A cross-national test of an institutional expla- nation, Economic Inquiry, vol. XXXV, Huntington Beach, California, Western Economic Association, July.

Kopits, G. and S. Symansky (1998): Fiscal Policy Rules, Occasional Paper $\mathrm{N}^{\circ} 162$, Washington, D.C., IMF.

Laffont, J. J. and J. Tirole (1993): A Theory of Incentives in Procurement and Regulation, Cambridge, Massachusetts, MIT Press.

Landes, D. S. (1999): The Wealth and Poverty of Nations: Why Some are So Rich and Some So Poor, New York, W.W. Norton \& Company.

La Porta, R., F. Lopez-de-Silanes, A. Shleifer and R. Vishny (1998): The quality of government, Cambridge, Massachusetts, August, mimeo.

Martino, A. (1989): Fisco e costituzione, in V. Uckmar (ed.), Esperienze straniere e prospettive per l'ordinamento tributario italiano, Padua, Italy, CEDAM.

Mattarella, B. G. (1994): La codification du droit: réflexions sur l'expérience française contemporaine, Revue française de droit administrative, vol. $10, \mathrm{~N}^{\circ} 4$, Paris, Sirey, JulyAugust.

Musgrave, R. A. (1959): The Theory of Public Finance, New York, McGraw-Hill.

North, D. C. and R. Thomas (1973): The Rise of the Western World: A New Economic History, Cambridge, U.K., Cambridge University Press.

North, D. C. and B. Weingast (1994): Constitutions and commitment: The evaluation of institutions governing public choice in seventeenth century England, in T. Persson and G. Tabellini (eds.), Monetary and Fiscal Policy, vol. 1, Cambridge, Massachusetts, MIT Press.

Nozick, R. (1974): Anarchy, State and Utopia, New York, Basic Books.

OECD (Organization for Economic Cooperation and Development) (1999): OECD Economic Outlook, Paris, December.

Poterba, J. M. and J. Von Hagen (eds.) (1999): Fiscal Institutions and Fiscal Performance, Chicago, Illinois, National Bureau of Economic Research, Inc. (NBER)/University of Chicago Press.

Potter, B. and J. Diamond (1999): Guidelines for Public Expenditure Management, Washington, D.C., IMF.

Rauch, J. E. and P. B. Evans (forthcoming): Bureaucratic structure and bureaucratic performance in less developed countries, Journal of Public Economics, Amsterdam, The Netherlands, Elsevier Science B.V.

Reviglio, F. (1999): Budget transparency for public expenditure control: The case of Italy, Washington, D.C., December, mimeo.

Rodotá, S. (1995): Le libertá e i diritti, in R. Romanelli (ed.), Storia dello Stato italiano, Rome, Donzelli Editore.

Schansberg, D. E. (1996): How Poor Government Policy Harms the Poor, Boulder, Colorado, Westview Press.

Sen, A. (1999): Development as Freedom, New York, Alfred A. Knopf.

Schick, A. (1998): Why most developing countries should not try New Zealand's reforms, The World Bank Research Observer, vol. 13, $\mathrm{N}^{\circ}$ 1, Washington, D.C., World Bank, February. 
Skaperdas, S. and C. Syropoulos (1995): Gangs as primitive states, in G. Fiorentini and S. Peltzman (eds.), The Economics of Organised Crime, Cambridge, U.K., Cambridge University Press.

Smith, D. and E. Richardson (1999): The readability of Australia's taxation laws and supplementary material: An empirical investigation, Fiscal Studies, vol. 20, $\mathrm{N}^{\circ} 3$, London, Institute for Fiscal Studies, September.

Tabellini, G. and T. Persson (forthcoming): Fiscal Policy in Representative Democracies, Cambridge, Massachusetts, MIT Press.

Tan, L. M. and G. Tower (1992): Readability of tax laws: An empirical study in New Zealand, Australian Tax Forum, vol. 9, $\mathrm{N}^{\circ}$ 3, Clayton, Victoria, Australia, Monash University.

Tanzi, V. (1995): Corruption: arm's-length relationships and markets, in G. Fiorentini and S. Peltzman (eds.), The Economics of Organised Crime, Cambridge, U.K., Cambridge University Press.

(1998a): Essential Fiscal Institutions in Selected Economies in Transition, Discussion paper, No. 53, Washington, D.C., Collegium Budapest, Institute for Advanced Study, November. (1998b): Corruption Around the World, Staff Papers, vol. 45, No. 4, Washington, D.C., IMF, December.

(forthcoming): Rationalizing the government budget: Or why fiscal policy is so difficult, in A. O. Krueger, Economic Policy Reform: The Second Stage, Chicago, Illinois, University of Chicago Press.

Tanzi, V. and T. Prakash (forthcoming): The cost of government and the use of public assets, Washington, D.C., mimeo.

Tanzi, V. and H. Zee (1997): Fiscal Policy and Long-Run Growth, Staff Papers, vol. 44, N 2, Washington, D.C., IMF, June.

United States Congress, Senate Committee on the Budget (1984): President's private sector survey on cost control (Grace Commission): Hearing before the Committee on the Budget, United States Senate, Ninety-Eighth Congress, First session, Washington, D.C., 7 November.

Van Creveld, M. (1999): The Rise and Decline of the State, Cambridge, U.K., Cambridge University Press.

World Bank (1997): The State in a changing world, World Development Report, Washington, D.C. 